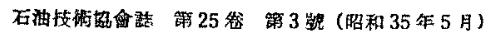

JOURNAL OF THE JAPANESE ASSOCIATION OF PETROLEUM TECHNOLOGISTS

VOL. 25. NO. 3 (May, 1960)

\title{
遊離ガス層に対する泥水の侵入に関する研究
}

\author{
藤 并 清 光 ${ }^{*}$
}

(昭和 35 年 2 月 18 日受理)

\section{A Study on the Invasion of Mud Fluid into Free Gas Zone}

By

Kiyomisu FuJII

\begin{abstract}
Results of a study on the invasion of mud fluid into free gas zone tested by the use of artificial consolidated sands are described in this paper. Some of the results obtained are as follows: (1) as mud pressure increases the speed of invasion increases, (2) barite mixed in mud fluid affects a little on the speed of invasion, (3) CMC in mud fluid decreases the speed of invasion, and (4) as the degree of reduction of gas permeability of sands by mud invasion, it is conspicuously smaller on the cores of originally lower permeability and on the cores of which mud invaded longer time.
\end{abstract}

\section{I. 研究の目的および研究方法}

ロータリー式で掘鋻する場合には，泥水の侵入のため に，茾戸を仕上げた後のガスの生産が非常に妨げられる ことがある。ガスは豊富に地下に存在しながら，掘籢方

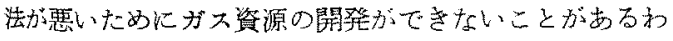
けである。それで著者仿この闍題を解くことを目的とし

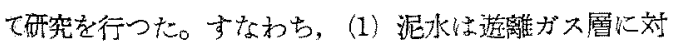
してどのような状態で侵入するものであるか，(2) 侵入 した泥水は遊離ガスの流動をどの上らに妨げられるもの であるか，(3）泥水の侵入を防くにはどうしたらよい かなどの点を明らかにす吕目的で研究を行つた。

これに関して行つた研究の一部はすでに発表されてい る゙。しかし，その研究では実験の数がたりい部分が

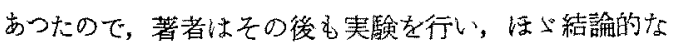
結果を得ることができた。それについてこフに觖し， さらに艺の結果を現場の作業に応用することについて記 可第である。

実験設借は以前の研究"と同じものである。すなわち 普通の泥水濾過試験装置の下側にコアーをとりつけたも のである。泥水に代少（普通は $7 \mathrm{~kg} / \mathrm{cm}^{2}$ ) を加える。そ

\footnotetext{
* 東京大学工学部探油教室
}

のために泥水の一部がコアーに侵大する。これがコアー の端に出たことを知るには，電気抵抗の変化を測定す る。その後に遡方向から空気を送り、コアーの洷透率を 測起する。この洷透率を元来のコアーの滲透率と比較し て, 泥水の䉕を判断する。この寒験ではすべて人士の アー（仯をせメントでかためたもの）を伎用した。

\section{II. 泥水の侵入の速さに関する実験}

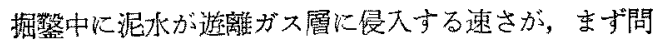
題になる。これに関して行つた奏験の結果が第1図であ

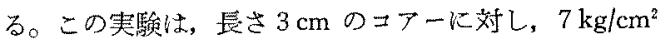
の王打で泥水を送つたものである。侵入の速さはコアー

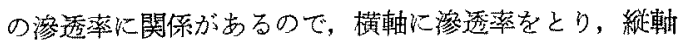

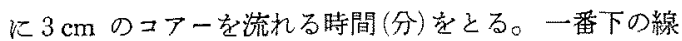
はヘントナイト泥水のみの場合である。この実験結果は 先の研究"に記してあるので，この网には測定点は記入 してなく，平均の値を示す線の及記入してるる。これに 使用したTベントナイトはよい種類のものでなく，奏験 に使用した澧度 $12 \%$ に招いても濾過水(30 分) は $13 \mathrm{cc}$ となる゙。第 1 图は，この怩水に刘して，ハシイトまた は CMCを混合した場合の奏験結果を示す。点の分布よ り判断すれば，泥水 $100 \mathrm{cc}$ に対しバライトを $68 \mathrm{~g}$ の割 
第 1 因泥水がラアーを流九る時間

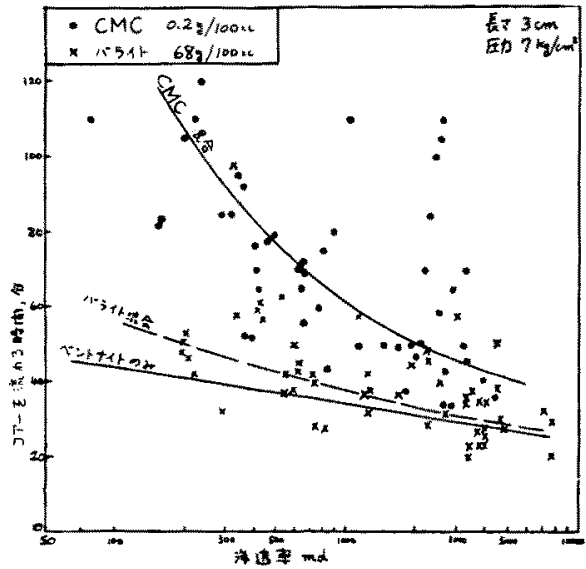

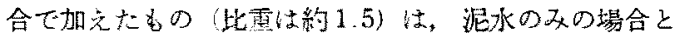
比較してごく敒か侵入時間が長くなる。泥水に0.2\%の CMC 它加完大場合心は，明らか心慢入時間が長くな る。一般に渗透率が小さくなるほど，但入時間が長くな

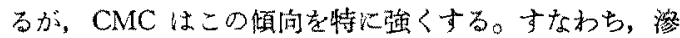

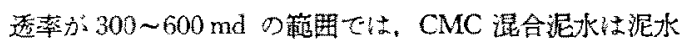

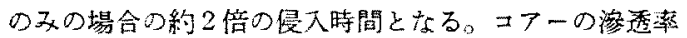
がこれより小さくなると，德入時間の比率はさらに大き

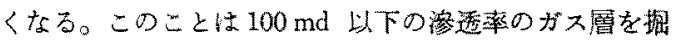

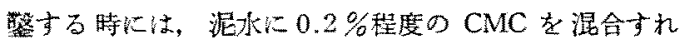
ば，泥水の侵入に対してよい結果を与えることを意味す

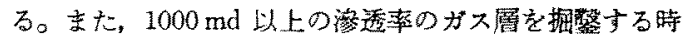
は，ど種類の泥水るかなり速く侵入することを意味す bo

泥水の王力が增加した埸合の，泥水の侵入特間に関し

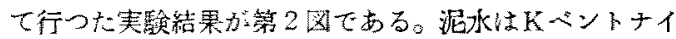
Wを腹度 $10 \%$ とて使用した。この時の蓇過水 (30 分)

第 2 图 泥水がコー妾流れる時間

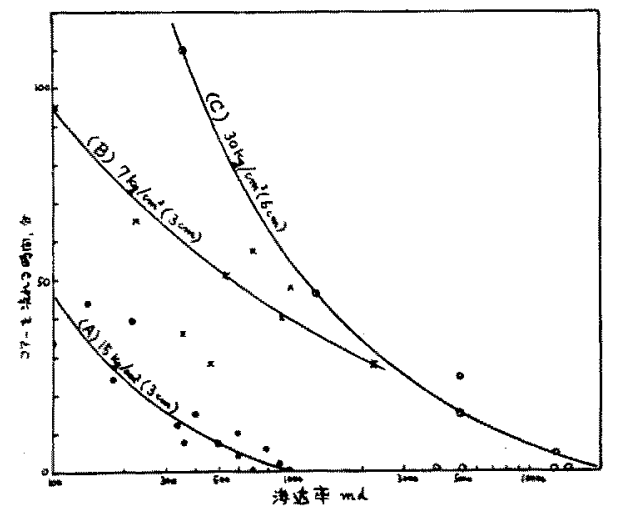

清光

は7 cc であるはななわらてペントナイトを使用した混

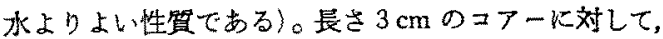
$7 \mathrm{~kg} / \mathrm{cm}^{*}$ のE力でこの菲水を送つた時の泥水が流れる

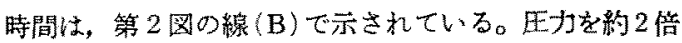
の $15 \mathrm{~kg} / \mathrm{cm}^{2}$ にした場合は線（A)で示されている。Aの

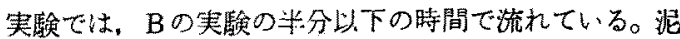

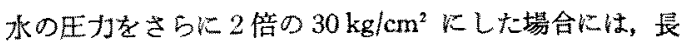

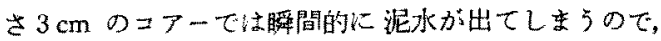

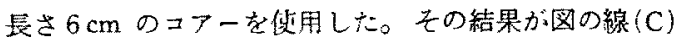
である。これい小さい澶迈率ては，流れる時間が長くな るよらな結果を西している。

以上の㬰験結果は，泥水の玨招が高くなるほど，泥 水がガス層に㤘入しゃすくなることを意味する。すなわ

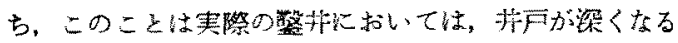
ほど，あるいは同じ深さでは泥水の地雷が商くなるは

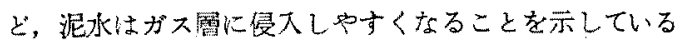

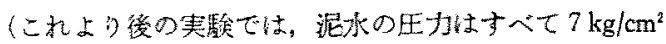
である)。

\section{III. ガスが通過し始める圧力に 関する実験}

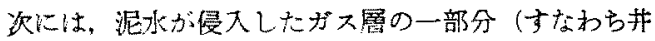
戸の周国）通過して、がスが流れることが閏題にな る。侵大した混水ががスの流れを好ける場合には，ガス

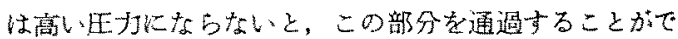

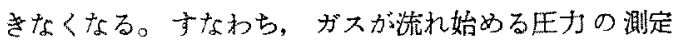

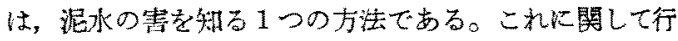

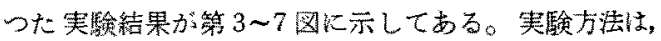
泥水の毁入したコアーに対して，侵入方向とは逆方向に 空気を遂る。まず小さい王力すなわらコアー $1 \mathrm{~cm}$ 当り $0.013 \mathrm{~kg} / \mathrm{cm}^{2}$ DE力で空気孛 15 分間送る。以下15分間 †ैつ $0.022,0.045,0.066,0.09,0.13,0.18,0.33$ $\mathrm{kg} / \mathrm{cm}^{2}$ の圧力を保らながら，狄第に言いE力にしてい

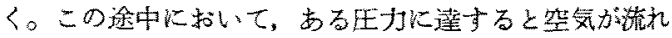

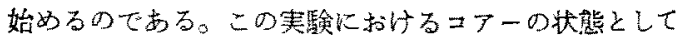

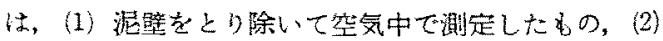
泥壁乱よび泥办が存在した状態で，逆方向から空気を送

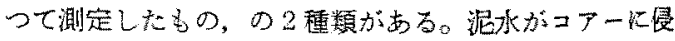
入する特間については，(1) 泥水がコアーの端に出た時

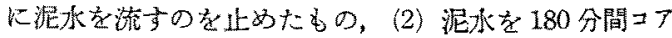

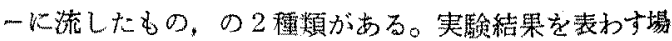
合には，(1)に対しては“出始めるぬて”之部し， (2)に対しては“180分”之記すことにする。(1)の 条件では普通の状態では25 60分のものが多い。した がつて，(2) の条件の180分山泥水老饬すことにより， 泥水の粒子がコアーのなかをらさぐこ上が考光られる。 
第 3 図は長さ $3 \mathrm{~cm}$ のコアーに対し普通のベントナイ 卜泥水を使用した場合について，空気の通過し始める王 力を測定した結果である。泥水はTベントナイトの 12 \%濃度のものである（以下の実験ではすべてこの泥水を 使用している)。この図でますす明らかなことは泥壁を とり除いた実験では，嚾かな例外を除けば、コア一の洨 透率に関保がなく，空気は低い圷力で通過し始めること である。これに反し，泥壁をつけたまっの状態では，筀 気性高い王力にならないと通過し始めない。このことは コアーの渗透率が低いはど著しい。泥壁をつけたまっの コアーでは, 泥水がコアーの端に出た時に, 泥水を流寸 ことをやめたコアーと，泥水を180 分流したュアーとの 間には，大きな差がない。泥壁をとり除くことは空気を 流机やすくすることに対し非常に有效であることが，上 の結果より判明した。しかし現場において，ガス層に対 してできた泥壁を完全にとり除くことは不可能である。 それで以下の実験では，なるべく実際の状熊に近ずける ために，泥壁乩よび泥水が存在する状態で実験を行つ た。

第 3 図空気の通過し始める现力

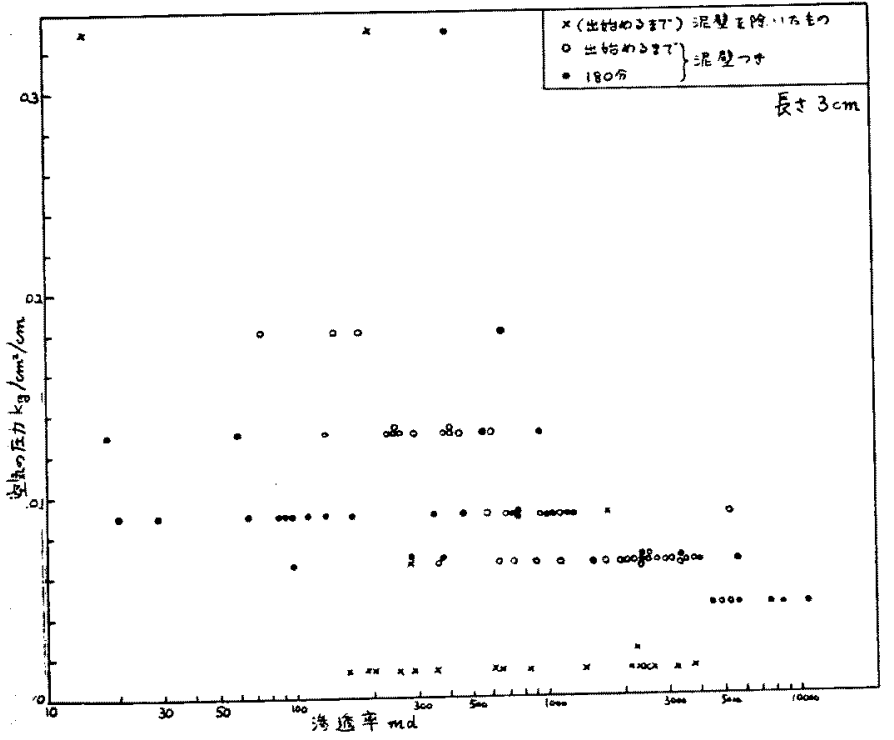

第 4 図空気の通過し始める王力（泥壁つを）

[CMC $0.2 \%$ 混合]

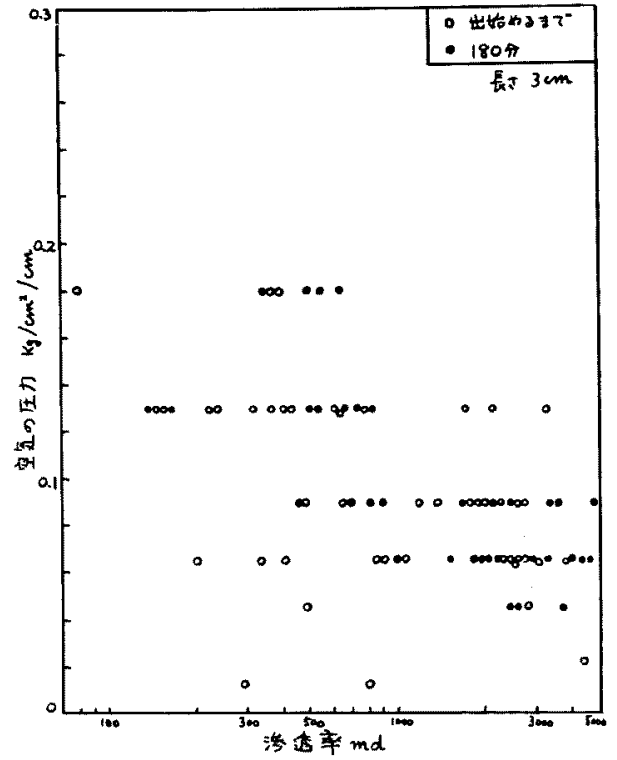

長さ $3 \mathrm{~cm}$ のコアーを使用しているこ とに注意すべきである。

第 5 図は泥水 $100 \mathrm{cc} に$ に゙ライトを $68 \mathrm{~g}$ の割合で混合した場合の実虚結 果である。この㢴と第 3 㘠を比較する ことにより，パライトの混合が空気の 通過し始める生力に影䍌を与えないこ とを意味する。次に第 6 图は，長さ6 cm のコアーに対し180 分間泥水学流 したコアーの，空気の通過し始める王 在求めた奏驗結果でする。コアー の長さ $1 \mathrm{~cm}$ 当りの玨力之渗透率の関 係,ならび CMC の作朋が明らかで ない点は，長さ $3 \mathrm{~cm}$ のコアーを侹用 した場合と全く同じである。次に第 7 図は初め水で飽和したコアー（長さ3 $\mathrm{cm})$ を使朋した奏験結果である。これ は元来水分の多い遊耀ガ大尿を仮定し

第 4 図は泥水に0.2\%の $\mathrm{CMC}^{*}$ 卆加克た場合の，空 気の通過し始める王力の実験結果である。この実臨にお いても泥水の流れる時間は，実験結果に大きな影垶を与 えない。第 3 图と第 4 図を比較してる大きな差はない。 このことは CMC の湿合が空気の通過し始める王うた

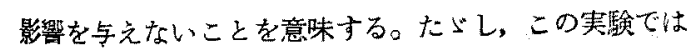

*就品名 O.W. 2
たものである。この実非英（泥水を流卞時間は180分）の 結果を第 3 図の結果と比較すると（第 7 図には測定が余 り多くないが，同じ傾向を示していることがわかる。

\section{IV. 淕透率の回復}

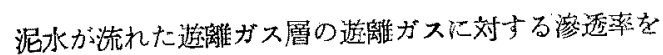
測定することにより，泥水の害を数学的に知ることがで 
第 5 図 空気の通過し始める圧力（泥壁つき） [バライト $68 \mathrm{~g} / 100 \mathrm{cc}$ 混合]

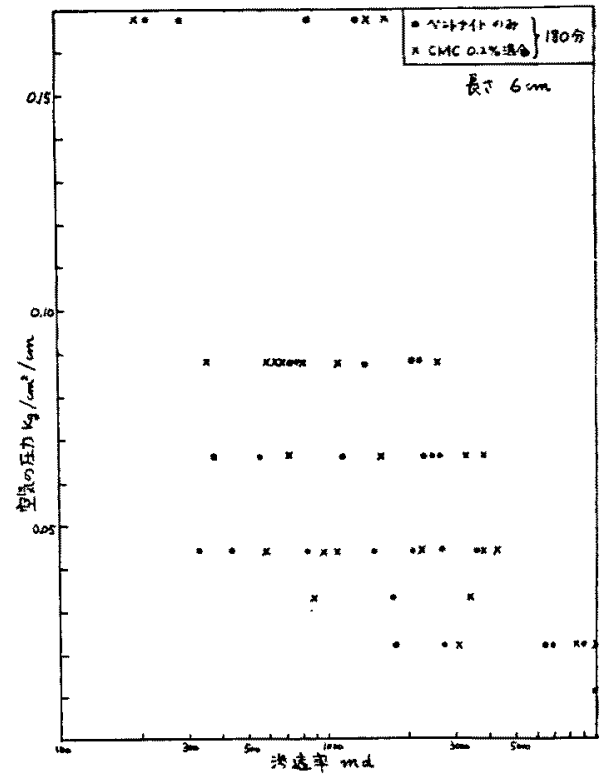

第 6 図 空気の通過し始める压力（泥整つ要) [चアーの長さ $6 \mathrm{~cm}]$

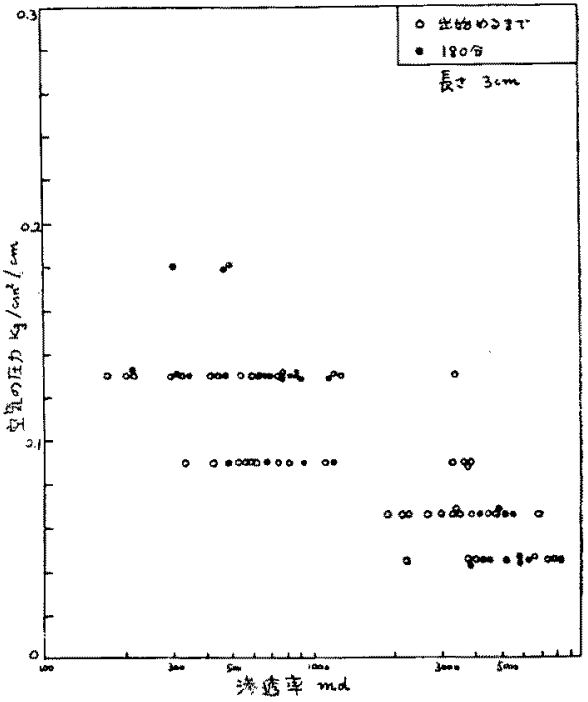

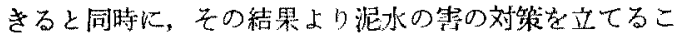
ともできる。これに関して行つた実銐は，一定時間，泥 水の流れたコアーに対して，前に示したよ5な順序で筀 気を送り，沴透率を測定する。これを元来のコアーの渗 透率（泥水を通す前の渗透率）に比較して百分率で表わ

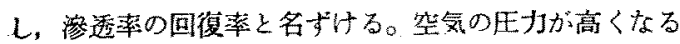

第 7 図空気の通過し始める区力（泥壁つき） [初め水を飽和したコアー]

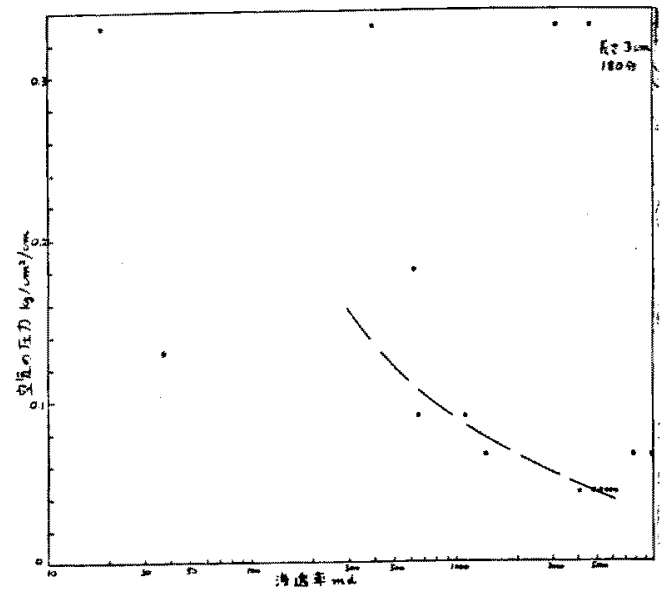

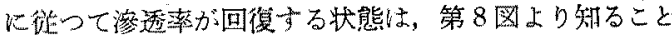

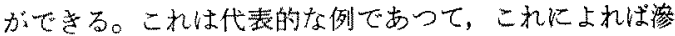

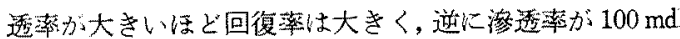
以下の埸合快，回復㸉は非常に小さくなつている。な

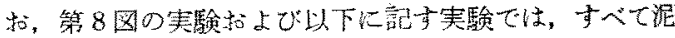
壁がついた来まのコア一を，泥水に接触した状態で測定 したものでちる。

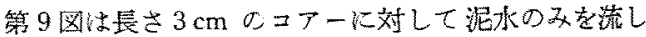

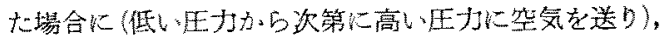
コア $-1 \mathrm{~cm}$ 当り $0.18 \mathrm{~kg} / \mathrm{cm}^{2}$ の然気の圧Jになつた時

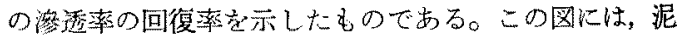
水が出始めるまで泥水を流したものと，180分泥水觉流

第 8 図瀿透率の回復（洒壁つき）

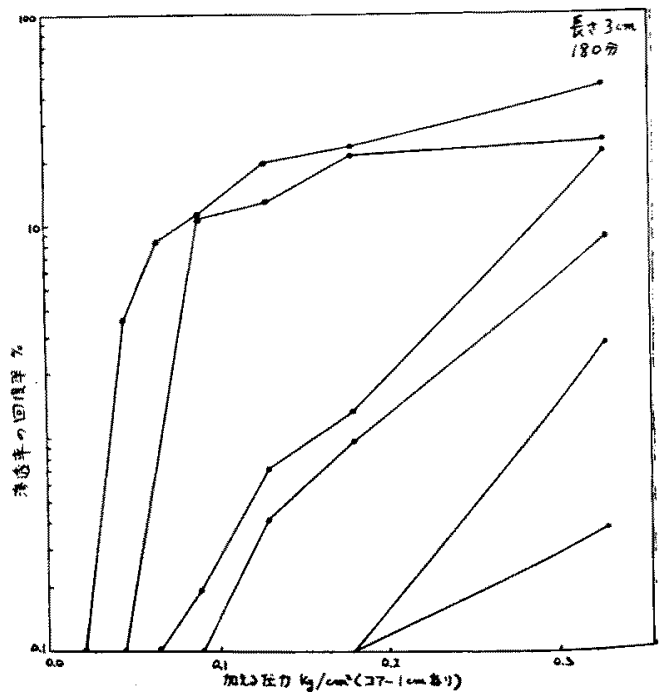


第 9 图泫透率の回復(泥壁つ总)

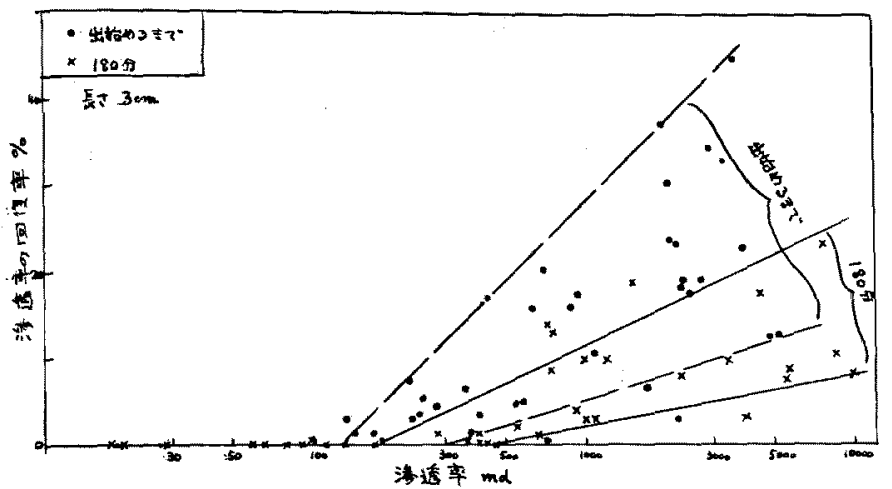

[驾気の生力: $0.18 \mathrm{~kg} / \mathrm{cm}^{2} / \mathrm{cm}$ ]

したるの (20 50 分) より，180 分間泥 水を流したものの方，明らか淩透率 の回復が小さいこと、などが助らかであ

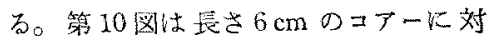
レて，第 9 図と同じ泥水を 180 分閐濨し た埸合の奏除結果である。测定点は筀気 の圷力がコ 东で行つた時の渗透率の回復率孝示寸。 これは第 9 图の180分の㝬験結果と大体 同じ傾间を示している。

第11図は第9図と同じュアーの条件 に対し，空気の玨力コアー $1 \mathrm{~cm}$ 当り $0.33 \mathrm{~kg} / \mathrm{cm}^{2}$ まで上げた塔合の渗透率の 回復率表示す。これによれば，空気の代

したものとの2 種頼の状態が記してかるにの图に物い て，実線まは破線は点の分布の範再を示しているう。 これによれば，(1) 滃透率が高いはど回復率が大きいこ

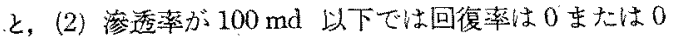
炕近しこと（3）泥水をコアーの端より出始るるまで流

第 10 図湾速の回復（记壁つき） [空気の压力: $0.17 \mathrm{~kg} / \mathrm{cm}^{2} / \mathrm{cm}$ ]

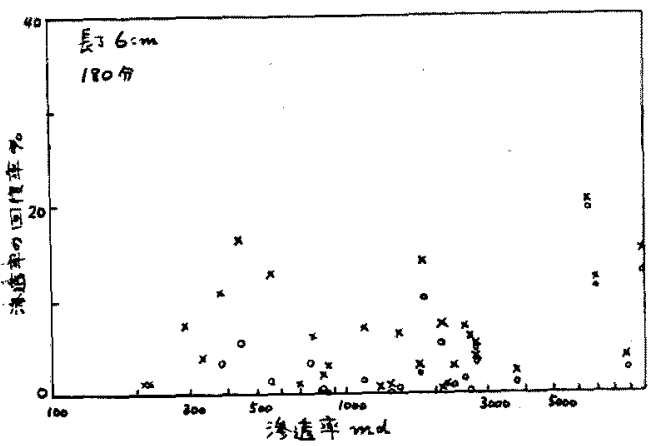

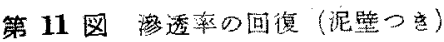
[空気の压力 : $0.33 \mathrm{~kg} / \mathrm{cm}^{2} / \mathrm{cm}$ ]

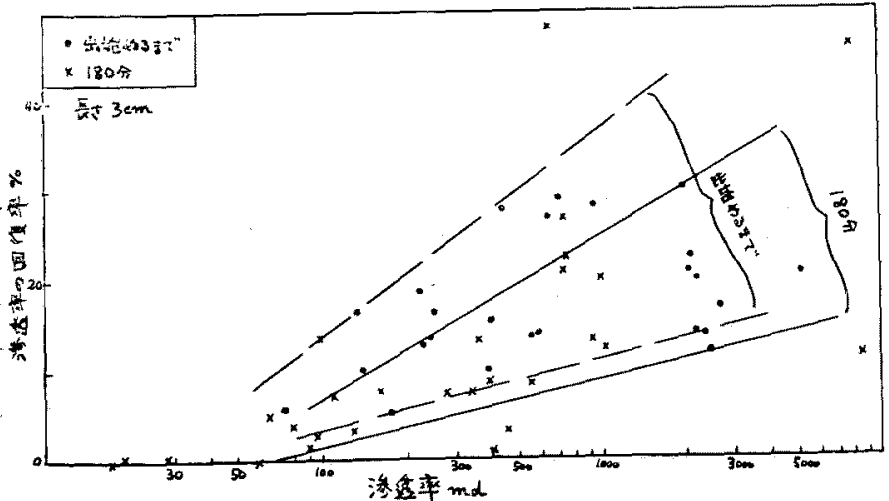

唀率の回復率は明 らかに大きくなつている。第12圈は 第 11 图上りさらK空無の王力在䯩く した舆駼結果である。これによれば， やはり空気の圧扔が高くなるほど，澺 透率の回復慗は大きくなつている。

第 13 図は泥水 $100 \mathrm{cc}$ に対しパシイ

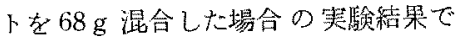
ある。バライトの混合以外の条件は第 9 図の実験と同じである。第 13 四を 第 9 図と比較することにより，バライ

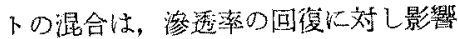
がないこと孛知ることがでさる。泥水 に效し CMC $0.2 \%$ 割会で混合し 


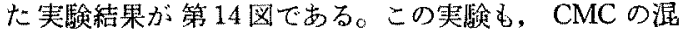
合以外の条件は第9図の実験と同じである。第 14 図を 第 9 図と比較することにより，CMCの混合は，渗透率

第 13 図滛透の回復(泥壁つき)，バライト $68 \mathrm{~g} / 100 \mathrm{cc}$ 鼬合 [䇥気の任力: $0.17 \mathrm{~kg} / \mathrm{cm}^{2} / \mathrm{cm}$ ]

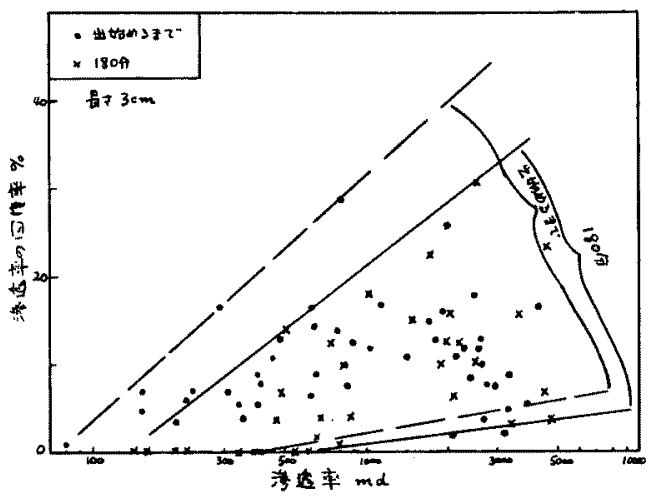

第 14 図滲透率の回復(㖊壁つ良)， CMC $0.2 \%$ 混合 [空気の厓力 $: 0.17 \mathrm{~kg} / \mathrm{cm}^{2} / \mathrm{cm}$ ]

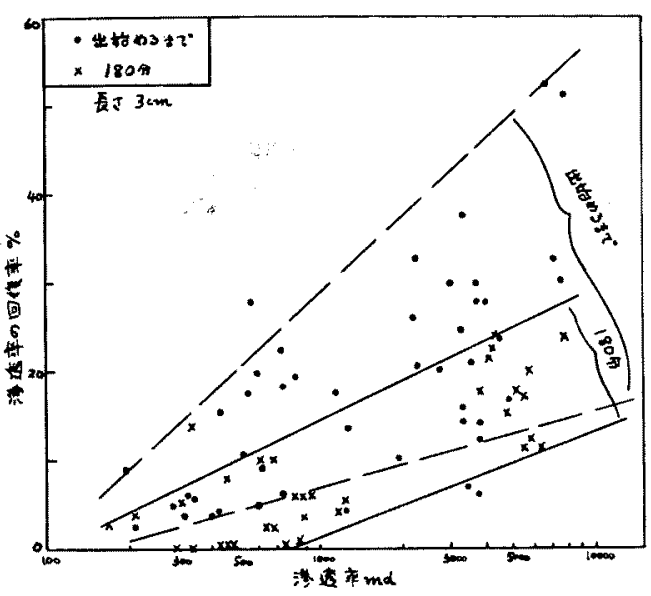

の回復に対し明らかな影鄉がないことを知ることができ る。た】しこの実嗝では長さ $3 \mathrm{~cm}$ のコアーを使用し ていることを忘れてはならない。

初め水を飽和させたコアーを健用した実験の結果が第 15 図である。これを第 9 図の 180 分泥水を流したコア 一の実験結果と比較すると，两者は同じ傾向にあること がかかる。このこより水の飽率が大きいことは渗透率 の回復率に影揞がないしとを知ることができる。

\section{V. 結論およびその応用}

遊離ガス膡に対する泥水の侵入の問題を明らがする ために研究を行つた。人工のコアーを伐用した実験結果 の要点を記せば，次のよ5になる。

（1）コアーに侵入して流れる泥水の速度は，コアー の溶透率が小さくなると幾分小さくなる。

（2）泥水の玨力が高くなる流ど，泥水の侵入速度は。 大きくなる。すなわち，泥水は挷户上り遠くまで侵入す b。

（3）泥水に湿合されたバライトは，泥水の速度をわ。 ずかに小さくする。

（4）泥水に混合された CMCは， $0.2 \%$ 混合割合 で明らかに泥水の侵入速度を小さくする。この CMCの 作用はコアーの滲超率が小さくなるほど著しい。

（5）泥水の侵入方向とは逆に空気を送る赛験では， 泥壁のとり除かれたコアーでは，非常に低い、诗空気 が流れ得る。

（6）泥壁をつけたまつのコアーでは，空気は高い压 力にならないと流れ始めない。このことはコアーの沴透 率が小さい任と著しい。

（7）泥水に対する $\mathrm{CMC}$ またはバライトの混合は，

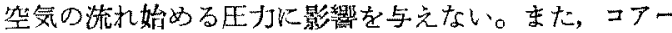
が初め水で飽和されたことも，空気の流れ始める王力に 関係がない。

（8）泥水の侵入したュアーの空気の沴透率の回復は， コアーの渗透睝が大きいはど，また空気のEカが高いは ど大さい。特に滲透率が $100 \mathrm{md}$ 以下のコアーでは，空

第 15 図 渗透臬の回復（泥壁つき），初め水を飽和したコアー [空気の压力: $0.17 \mathrm{~kg} / \mathrm{cm}^{2} / \mathrm{cm}$ ]

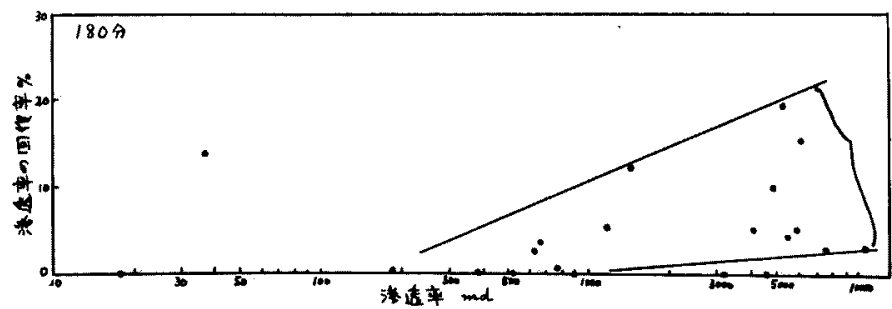

気の压加が高くないと渗透率の回復率 は0に近い。

（9）泥水をコアーの端より出始め るまで流したもの (20〜50分)より， 180 分間泥水を流したものの方が澺透 率の回復は小さい。

（10）泥水飞混合された CMC また

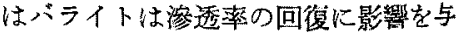
光ない。また，初めコアーが水で飽和 されていたこと回復に関係がない。 
以上の結論は人工のコアーを使用した実験の結果より

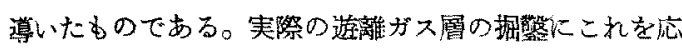
用するには，少し説明を加之なければならない。例党

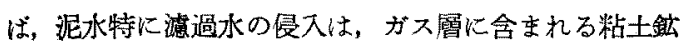
物の膨潤の原因となり，ガスの流れを大きく妨げる。こ のようなことを加え、さらに前回の舫究”の結果も加壳 て，実際の作業について注意すべきことを記すならば， 以下のようになる。

(1) ガスのE力が非常に高い場合を除けば，一般に

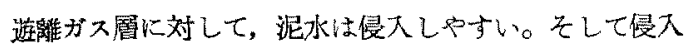
した泥水はガスの流れを非常に好げる。

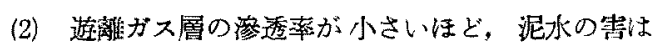
大きく現われる。特に $100 \mathrm{md}$ 以下の遊離ガス層の開発 には注意しなければならない。

（3）遊離ガス層を掘鳖する場合には，泥水の比重を なるべく小さくすること，およびガス屬が泥水に接触す る時間ななるべく少なくすること(すなるち速く仕上げ
ること)の 2 項目が最必必要なことである。

(4) 泥水の侵大を防ぐ1つの方法は, 泥水のベント ナイトの濃度を高くすること，末たは CMC を混合する ことである。特に灙透が $100 \mathrm{md}$ 以下の遊離ガス層を 据擎する時には，必ず CMC を0.2\%程度混合するこ とを実行しなければならない。

（5）ガスの流れを最も奶げるものは壮户の周困の泥 壁である。それで挷戸仕上げにさいしては，泥壁をなる ベく薄くすること、あるい忧壁をとり除く上うに努力 すべきである。例えばケーシングに詨するスクラッチヤ 一の使用などを考兄るべきである。

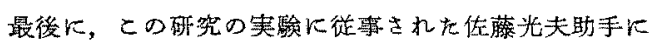
奶し，厚く感謝の意を表す次第である。

\section{参考文献}

1）藤井清光：遊離ガス周に対与る泥水の侵入，石油 技術協会誌, 23 巻 6 号, 昭和 33 年 11 月. 